\title{
Pemanfaatan Bakteri Pseudomonas Flourescens Rh4003 dan Asam Askorbat untuk Mempertahankan Viabilitas Benih Padi Hibrida
}

\section{The Utility of Pseudomonas flourescens RH4003 and Ascorbic Acid to Maintain Hybrid Rice Seed Viability}

\section{A. A. Keswari Krisnandika, Eny Widajati * dan Abdjad Asih Nawangsih}

Departemen Agronomi dan Hortikultura, Fakultas Pertanian, Institut Pertanian Bogor (Bogor Agricultural University), Jl. Meranti, Kampus IPB Darmaga, Bogor 16680, Indonesia Telp.\&Faks.62-251-8629353 e-mail agronipb@indo.net.id *Penulis untuk korespondensi: eny_widajati@yahoo.co.id

Disetujui 17 Mei 2017/Published online 22 Mei 2017

\begin{abstract}
Hybrid rice has an open glume that plays important role in deceleration rate of seed viability during storage time. As well to reach optimum yield hybrid rice also need high quality nutrient intake. This research was performed to study the effect of seed coating formula with the addition of the bacteria Pseudomonas flourescens RH40O3 as Plant Growth Promoting Rhizobacteria and ascorbic acid as an antioxidant, against the viability of hybrid rice seeds in storage. This study consist of 3 (three) serial experiment, using 3 different variety of hybrid rice i.e., DG-1, Intani and SL-8 respectively. The experimental design was nested plot design with 6 (six) times period of storage as a main plot. The results showed that coating using ascorbic acid is the best treatment for almost all variables of viability in almost all varieties. Bacterial treatment has highly significant $(p<0.01)$ increase the speed growth rate and vigour index in the sixth weeks of storage of $22.48 \%$ per etmal and $83.33 \%$ to varieties SL-8.Coating rice seeds DG1 using ascorbic acid in the sixth weeks resulted in the highest vigour index (90\%) are significant ( $p<0.5)$ and highly significant increase the seed germination and vigour index in the ninth weeks of storage to varieties SL-8 SHS (92.67\% and $73.33 \%)$.
\end{abstract}

Keywords : ascorbic acid, hybrid rice, pseudomonas flourescens, storage, viability

\section{ABSTRAK}

Padi hibrida memiliki glume terbuka yang berperan penting pada laju perlambatan viabilitas benih selama penyimpanan. Serta untuk mencapai hasil panen padi hibrida yang optimal membutuhkan asupan nutrisi yang berkualitas tinggi. Penelitian ini bertujuan untuk mempelajari pengaruh formula lapisan benih dengan penambahan bakteri Pseudomonas fluorescens RH4003 sebagai Pertumbuhan Tanaman Memnghasilkan Rhizobakteri dan asam askorbat sebagai antioksidan, menghambat viabilitas benih padi hibrida dalam penyimpanan. Penelitian ini terdiri dari tiga seri percobaan, yaitu menggunakan 3 varietas padi hibrida (DG-1, Intani dan SL-8), Rancangan percobaan yang digunakan yaitu petak bersarang dengan enam kali periode penyimpanan sebagai petak utama. Hasil penelitian menunjukkan bahwa lapisan yang menggunakan asam askorbat merupakan perlakuan terbaik dari semua variabel viabilitas hampir pada semua varietas. Perlakuan dengan menggunakan bakteri memiliki hasil yang signifikan $(p<0.01)$ meningkatkan laju pertumbuhan dan indeks vigor pada minggu keenam penyimpanan sebesar $22.48 \%$ per etmal dan $83.33 \%$ untuk varietas benih padi SL-8. Lapisan DG-1 yang menggunakan asam askorbat pada minggu keenam mengakibatkan indeks vigor tertinggi $(90 \%)$ yang signifikan $(p<0.5)$ dan peningkatan yang sangat signifikan pada perkecambahan benih dan indeks vigor minggu kesembilan penyimpanan untuk varietas SL-8 SHS (92.67\% dan 73.33\%). 


\section{PENDAHULUAN}

Padi hibrida merupakan teknologi alternatif yang dapat meningkatkan produksi padi hingga 15$20 \%$ dibandingkan dengan padi inbrida (Deptan, 2007). Penggunaan padi hibrida diharapkan dapat memenuhi kebutuhan beras nasional di tengah keterbatasan lahan pertanian. Kendala yang dihadapi dalam pengembangan padi hibrida saat ini yaitu ketersediaan benih padi hibrida berkualitas tinggi dengan harga terjangkau. Kelangkaan benih padi hibrida ini terkait dengan sulitnya mempertahankan viabilitas benih padi hibrida di penyimpanan. Viabilitas benih padi hibrida dalam suhu kamar dapat dipertahankan sampai tiga bulan sekitar $85 \%$ dan akan menurun secara signifikan (Pablico, 2006). Hal ini terkait dengan rekayasa genetik pada tetua padi hibrida melalui sistem Cytoplasmic Male Sterile (CMS), yang menyebabkan benih padi hibrida memiliki kulit halus, glume terbuka dan dosis asam giberelin tinggi sehingga mendukung pertumbuhan jamur di penyimpanan yang mempercepat laju kemunduran mutu benih (Srivastava et al., 2008). Padi hibrida juga memiliki mutu fisik yang kurang tahan terhadap serangan hama penyakit (Dadang et al., 2009).

Kemunduran mutu benih di penyimpanan tidak dapat dicegah namun dapat diperlambat melalui seed treatment (Giang dan Gowda, 2007). Seed treatment khusus seperti priming (osmoconditioning atau matriconditioning), coating, pelleting biasanya digunakan untuk meningkatkan perkecambahan atau melindungi benih dari patogen (Ilyas, 2006). Seed coating juga memberikan peluang untuk pelapisan yang lebih baik dengan beberapa material yang dapat memperbaiki perkecambahan dan pertumbuhan benih (Kunkur $e t$ al., 2007).

Dewasa ini, seed coating tidak hanya digunakan untuk mempertahankan viabilitas dan vigor benih saja tetapi juga dapat diintegrasikan dengan penambahan antioksidan maupun mikroba untuk menunjang pertumbuhan tanaman. Pseudomonas flourescens merupakan salah satu mikroba yang dapat memacu pertumbuhan tanaman, merevegetasi lahan, serta agen biokontrol beberapa jenis patogen terkait dengan kemampuan bakteri ini dalam memproduksi fitohormon seperti auksin (Jeon, 2003) (menurut Khakipour et al., (2008) P. flourescens mampu menghasilkan auksin yang berkisar antara 0.0-31.6 $\mathrm{mg} / \mathrm{l})$, siredofor (Kazempour, 2004), serta dapat memacu peningkatan enzim-enzim pertahanan yaitu Peroksidase (PO), katalase, Fenilalanin Amonia Liase (PAL) dan Fenol Poli Oksidase (PPO) (Paul dan Sarma, 2005) serta kitin dan fenol (Anita dan Samiyappan, 2012)

Asam askorbat merupakan salah satu antioksidan yang dapat digunakan pada benih untuk menangkal radikal bebas (senyawa penyebab kemunduran benih). Lumbanraja (2006) menyatakan perendaman benih pepaya dengan asam askorbat $350 \mathrm{ppm}$ mampu secara nyata meningkatkan vigor kekuatan tumbuh benih dengan tolok ukur $\mathrm{T}_{50}$. Pada periode awal simpan benih benih tanpa perlakuan memiliki $\mathrm{T}_{50}$ sebesar 11.64 HST sementara benih yang diberi perlakuan asam askorbat memiliki $\mathrm{T}_{50}$ sebesar 9.63 HST. Setelah 12 minggu penyimpanan, benih tanpa perlakuan memiliki $\mathrm{T}_{50}$ sebesar 12.98 HST sementara benih yang diberi perlakuan asam askorbat memiliki $\mathrm{T}_{50}$ sebesar 10.94 HST.

Penelitian ini bertujuan untuk mempelajari pengaruh penggunaan bakteri Pseudomonas flourescens dan asam askorbat dalam seed coating, untuk mempertahankan viabilitas benih padi hibrida di penyimpanan.

\section{BAHAN DAN METODE}

Penelitian ini dilaksanakan pada bulan Januari hingga Juli 2012. Perbanyakan bakteri dilakukan di Laboratorium Bakteriologi, Departemen Proteksi Tanaman, Fakultas Pertanian, Institut Pertanian Bogor, Darmaga Bogor. Coating dikerjakan di PT. East West Seed Indonesia. Penyimpanan dan pengujian benih dilaksanakan di Laboratorium Ilmu dan Teknologi Benih, Departemen Agronomi dan Hortikultura, Fakultas Pertanian, Institut Pertanian Bogor, Dramaga Bogor.

Benih padi hibrida yang digunakan dalam penelitian ini adalah varietas SL-8 (tanggal panen 26-27 September 2011), DG-1 (tanggal panen 16 September 2011) dan Intani 2 (tanggal panen 02 November 2011). Biakan murni bakteri Pseudomonas flourescens (RH4003) diperoleh dari isolasi agen biokontrol penyakit Ralstonia solanacearum pada tanaman tomat yang dilakukan oleh Nawangsih (2006). Media King's B untuk peremajaan bakteri dan polimer sintetik sebagai perekat, asam askorbat $350 \mathrm{ppm}$, aquades, alkohol $70 \%$, kertas label, plastik bening dan kertas merang untuk media perkecambahan.

Alat yang digunakan yaitu cawan petri, cawan porselen, pinset, bunsen, hand sprayer, tabung erlenmeyer, tabung reaksi, rak tabung, autoklaf, mikropipet, luminar air flow, rotary coater, timbangan analitik, oven, desikator, alat pengepres kertas, alat pengecambah benih (APB) IPB 73 2A/B, gelas ukur, spatula, blender dan alat tulis.

Rancangan yang digunakan dalam penelitian ini ialah Rancangan Petak Tersarang. Petak utama adalah periode simpan yang terdiri dari enam taraf yaitu: $\mathrm{P} 0=0$ minggu, $\mathrm{P} 3=9$ minggu, $\mathrm{P} 1=3$ minggu, $\mathrm{P} 4=12$ minggu, $\mathrm{P} 2=6$ minggu, $\mathrm{P} 5=15$ minggu

Faktor kedua, formulasi coating sebagai anak petak terdiri dari tiga taraf, yaitu $\mathrm{C} 0$ 
(kontrol,tanpa coating), C1 (Polimer + isolat $P$. flourescens RH4003), dan C2 (Polimer + asam askorbat $350 \mathrm{ppm})$

Penelitian menggunakan 3 ulangan, sehingga didapatkan kombinasi 54 satuan percobaan. Percobaan menggunakan rancangan percobaan yang sama dilakukan secara terpisah pada 3 varietas padi hibrida sehingga secara keseluruhan terdapat 162 unit satuan percobaan. Data hasil percobaan dianalisis menggunakan analisis ragam (uji F) dan uji lanjut Duncan Multiple Range Test (DMRT) pada taraf nyata $5 \%$.

Peremajaan isolat bakteri $P$. fluorescens RH4003 dilakukan pada media padat King's B secara aseptik, kemudian diinkubasi pada suhu ruang $\left(27^{\circ} \mathrm{C}-28^{\circ} \mathrm{C}\right)$ selama 48 jam untuk mendapatkan koloni tunggal. Koloni tunggal hasil peremajaan kemudian digores penuh pada cawan petri steril baru yang telah berisi media padat King's B, kemudian diinkubasi selama 48 jam pada suhu ruang. Setelah 48 jam bakteri siap dipindahkan ke media cair (NB) dengan cara: memasukkan $5 \mathrm{ml}$ air steril ke dalam cawan petri berisi goresan penuh bakteri yang bebas dari kotaminan kemudian dischrub menggunakan jarum ose agar bakteri tercampur dalam air. Suspensi air steril dan bakteri tersebut diambil sebanyak $400 \mu(0.4 \mathrm{ml})$ dan dimasukkan dalam media cair Nutrienth Broth (NB) $250 \mathrm{ml}$, ditutup aluminium foil, direkatkan dan dishaker $100 \mathrm{rpm}$ selama 48 jam. Formula siap digunakan. Sementara, untuk mendapatkan formula coating asam askorbat $350 \mathrm{ppm}$ dilakukan dengan cara melarutkan $389 \mathrm{mg}$ asam askorbat $90 \%$ dalam 1 1 aquades.

Kerapatan awal bakteri dihitung secara aseptik dengan metode pencawanan berseri yaitu

1. Pengenceran: suspensi bakteri diambil $100 \mu(0.1$ ml) dari media cair NB yang telah dishaker selama 48 jam. Kemudian dimasukkan ke tabung berisi $9 \mathrm{ml}$ air steril serta dihomogenkan menggunakan vortex (tabung 1 pengenceran $10^{1}$ ). Suspensi bakteri yang sudah homogen dipipet kembali $1 \mathrm{ml}$ (tabung 1) kemudian dimasukkan ke tabung 2 yang berisi $9 \mathrm{ml}$ air steril, dihomogenkan kembali, diperoleh tabung 2 dengan pengenceran $10^{2}$ begitu seterusnya hingga diperoleh pengenceran $10^{8}$.

2. Platting menggunakan 2 ulangan (duplo) untuk setiap pengenceran $10^{1}, 10^{3}, 10^{5}, 10^{6}, 10^{7}, 10^{8}$. Sebanyak $0.1 \mathrm{ml}$ suspensi bakteri diambil dari masing-masing tabung, kemudian disebar pada petri dengan media padat King's B menggunakan gelas penyebar. Petri lalu direkatkan menggunakan seal dan diletakkan dalam posisi terbalik untuk mencegah uap air yang dapat menimbulkan kontaminan. Pengamatan terhadap koloni yang tumbuh dilakukan setelah inkubasi selama 24 jam dan 48 jam pada suhu kamar.
Pelapisan benih padi hibrida dilakukan sesuai dengan taraf perlakuan. Suspensi bakteri yang digunakan memiliki kerapatan berkisar antara $10^{\circ}$ $10^{10} \mathrm{cfu} / \mathrm{ml}$. Perbandingan antara supensi bakteri dan larutan asam askorbat dengan polimer yaitu 10:19. Coating dilakukan menggunakan alat Rotary Coater. Benih yang telah dilapisi dikeringkan kembali sampai kadar air aman untuk disimpan yaitu $<11 \%$. Benih selanjutnya dikemas ke dalam kemasan plastik poliethylen dan direkatkan (seal) untuk kemudian disimpan di Laboratorium Ilmu dan Teknologi Benih selama 0, 3, 6, 9, 12 dan 15 minggu.

Viabilitas potensial diuji menggunakan tolok ukur daya berkecambah dan berat kering kecambah normal. Viabilitas total diukur dengan melihat potensi tumbuh maksimum. Vigor kekuatan tumbuh benih diuji menggunakan tolok ukur indeks vigor dan kecepatan tumbuh. Pengujian dilakukan dengan cara mengecambahkan benih pada media kertas merang menggunakan metode Uji Kertas Digulung didirikan dalam plastik $\left(\mathrm{UKD}_{\mathrm{dp}}\right)$. Alat pengecambah benih yang digunakan IPB 73 2A/B. Setiap perlakuan terdiri atas tiga ulangan dan setiap ulangan terdiri dari 50 butir benih.

Tolok ukur yang diamati untuk mengukur daya simpan benih padi hibrida meliputi: kadar air benih (KA), daya berkecambah (DB), berat kering kecambah normal (BKKN), potensi tumbuh maksimum (PTM), kecepatan tumbuh $\left(\mathrm{K}_{\mathrm{CT}}\right)$ dan indeks vigor (IV).

\section{HASIL DAN PEMBAHASAN}

Secara umum, terjadi peningkatan viabilitas benih selama periode penyimpanan. Kadar air benih berfluktuasi selama periode simpan namun masih dalam kisaran $9.71 \%$

\section{Pengaruh Coating terhadap Daya Simpan Benih Padi Hibrida DG-1}

Interaksi faktor tunggal periode simpan dan perlakuan coating berpengaruh nyata terhadap indeks vigor dan sangat nyata terhadap berat kering kecambah normal. Sementara, faktor tunggal periode simpan berpengaruh nyata terhadap kecepatan tumbuh dan berat kering kecambah normal, faktor tunggal perlakuan coating berpengaruh nyata terhadap tolok ukur kadar air dan sangat nyata pada tolok ukur berat kering kecambah normal (Tabel 1.). Daya berkecambah benih yang diberi perlakuan coating maupun tanpa coating tidak berbeda nyata sampai periode simpan 15 minggu, tetap tinggi dengan kisaran 96.00-98.67\%. Begitu pula dengan potensi tumbuh maksimum berkisar antara $98.00-98.67 \%$. 
Tabel 1. Rekapitulasi Sidik Ragam Pengaruh Perlakuan Coating dan Periode Simpan pada Benih Padi Hibrida DG-1

\begin{tabular}{lcccc}
\hline \multirow{2}{*}{ Tolok ukur } & \multicolumn{4}{c}{ Perlakuan dan interaksinya } \\
\cline { 2 - 5 } & PS & P & PSXP & KK $(\%)$ \\
\hline DB & tn & tn & tn & 4.02 \\
KCT & $*$ & tn & tn & 6 \\
IV & tn & tn & $*$ & 13.77 \\
PTM & tn & tn & tn & 1.6 \\
BKKN & $*$ & $* *$ & $* *$ & 12.08 \\
KA & tn & $*$ & tn & 10.99 \\
\hline Keterangan : tn = tidak berpengaruh nyata, * $=$ \\
\multicolumn{5}{c}{ berpengaruh nyata pada taraf 5\% DMRT $* *=$} \\
berpengaruh nyata pada taraf 1\% DMRT, KK $=$ \\
koefisien keragaman
\end{tabular}

Tabel 2. menunjukkan periode simpan secara nyata mengalami peningkatan kecepatan tumbuh dan berat kering kecambah normal terutama pada periode simpan 15 minggu.

Tabel 2. Pengaruh Periode Simpan pada Benih Padi Hibrida DG-1

\begin{tabular}{|c|c|c|c|c|c|c|}
\hline \multirow{2}{*}{$\begin{array}{l}\text { Tolok } \\
\text { Ukur }\end{array}$} & \multicolumn{6}{|c|}{ Periode Simpan (Minggu) } \\
\hline & 0 & 3 & 6 & 9 & 12 & 15 \\
\hline $\begin{array}{c}\text { KCT } \\
\text { (\% per } \\
\text { etmal) }\end{array}$ & $\begin{array}{c}18.64 \\
\mathrm{c}\end{array}$ & $\begin{array}{l}18.44 \\
\mathrm{c}\end{array}$ & $\begin{array}{c}21.04 \\
\mathrm{ab}\end{array}$ & $\begin{array}{c}20.53 \\
b\end{array}$ & $\begin{array}{l}19.05 \\
\mathrm{c}\end{array}$ & $\begin{array}{c}22.06 \\
\mathrm{a}\end{array}$ \\
\hline $\begin{array}{c}\text { BKKN } \\
(\mathrm{g})\end{array}$ & $\begin{array}{c}0.28 \\
b\end{array}$ & $\begin{array}{c}0.23 \\
\mathrm{c}\end{array}$ & $\begin{array}{c}0.29 \\
b\end{array}$ & $\begin{array}{c}0.32 \\
b\end{array}$ & $\begin{array}{c}0.32 \\
b\end{array}$ & $\begin{array}{c}0.39 \\
\mathrm{a}\end{array}$ \\
\hline \multicolumn{7}{|c|}{$\begin{aligned} \text { Keterangan : } & \text { Nilai rata-rata yang diikuti oleh huruf yang sama } \\
& \text { menunjukkan tidak berbeda nyata pada taraf } 5 \% \\
& \text { berdasarkan analisis DMRT. }\end{aligned}$} \\
\hline \multicolumn{7}{|c|}{$\begin{array}{l}\text { Perlakuan coating menggunakan bakteri } \\
\text { memberikan pengaruh yang nyata terhadap kadar } \\
\text { air dibandingkan dengan perlakuan tanpa coating } \\
\text { (Tabel 3.). }\end{array}$} \\
\hline Tabel 3. & $\begin{array}{l}\text { Penga } \\
\text { Padi }\end{array}$ & brida I & $\begin{array}{l}\text { kuan } \\
\mathrm{J}-1\end{array}$ & Coatin & pada & Benih \\
\hline \multirow{2}{*}{$\begin{array}{l}\text { Tolok } \\
\text { ukur }\end{array}$} & \multicolumn{6}{|c|}{ Perlakuan } \\
\hline & \multicolumn{2}{|c|}{ Bakteri } & \multicolumn{2}{|c|}{$\begin{array}{c}\text { Asam } \\
\text { askorbat }\end{array}$} & \multicolumn{2}{|c|}{ Tanpa coating } \\
\hline BKKN & \multicolumn{2}{|c|}{$0.27 \mathrm{~b}$} & \multicolumn{2}{|c|}{$0.31 \mathrm{a}$} & \multicolumn{2}{|c|}{$0.33 a$} \\
\hline KA & \multicolumn{2}{|c|}{$9.44 \mathrm{~b}$} & \multicolumn{2}{|c|}{$9.56 \mathrm{ab}$} & \multicolumn{2}{|c|}{$10.11 \mathrm{a}$} \\
\hline
\end{tabular}

Indeks vigor tetap dapat dipertahankan sampai dengan akhir penyimpanan baik pada perlakuan coating maupun tanpa coating dengan rataan $94.00 \%$. Pada periode simpan 6 minggu, perlakuan coating menggunakan asam askorbat menghasilkan indeks vigor yang nyata lebih tinggi dibandingkan tanpa coating (Tabel 4.)
Tabel 4. Interaksi Perlakuan dengan Periode Simpan terhadap Tolok Ukur Indeks Vigor pada Benih Padi Hibrida DG-1

\begin{tabular}{|c|c|c|c|c|c|c|}
\hline \multirow{2}{*}{$\begin{array}{l}\text { Perlakuan } \\
\text { coating }\end{array}$} & \multicolumn{6}{|c|}{ Periode simpan (minggu) } \\
\hline & 0 & 3 & 6 & 9 & 12 & 15 \\
\hline & \multicolumn{6}{|c|}{$\%$} \\
\hline \multirow{3}{*}{ Bakteri } & 81.3 & 65.3 & 71.3 & 79.3 & 80.0 & 93.3 \\
\hline & 3 & 3 & 3 & 3 & 0 & 3 \\
\hline & $a-d$ & def & $c-f$ & a-e & a-e & $\mathrm{ab}$ \\
\hline \multirow{3}{*}{$\begin{array}{l}\text { Asam } \\
\text { askorbat }\end{array}$} & 65.3 & 53.3 & 90.0 & 92.0 & 68.6 & 92.0 \\
\hline & 3 & 3 & 0 & 0 & 7 & 0 \\
\hline & def & $\mathrm{f}$ & $a b c$ & $\mathrm{ab}$ & def & $\mathrm{ab}$ \\
\hline \multirow{3}{*}{$\begin{array}{l}\text { Tanpa } \\
\text { coating }\end{array}$} & 76.6 & 72.0 & 61.3 & 82.6 & 82.6 & 98.0 \\
\hline & 7 & 0 & 3 & 7 & 7 & 0 \\
\hline & b-e & $c-f$ & ef & $\mathrm{a}-\mathrm{d}$ & $a-d$ & $\mathrm{a}$ \\
\hline
\end{tabular}

Tabel 5. menunjukkan pada periode akhir penyimpanan, perlakuan coating maupun tanpa coating tidak berbeda nyata berdasarkan tolok ukur berat kering kecambah normal. Selama periode simpan terjadi peningkatan bobot kering kecambah normal terutama pada periode simpan 15 minggu.

Tabel 5. Interaksi Perlakuan dengan Periode Simpan terhadap Tolok Ukur Bobot Kering Kecambah Normal pada Benih Padi Hibrida DG-1

\begin{tabular}{lcccccc}
\hline \multirow{2}{*}{$\begin{array}{l}\text { Perlakuan } \\
\text { coating }\end{array}$} & \multicolumn{7}{c}{ Periode simpan (minggu) } \\
\cline { 2 - 7 } & 0 & 3 & 6 & 9 & 12 & 15 \\
\cline { 2 - 7 } Bakteri & 0.2 & 0.1 & 0.1 & 0.2 & 0.31 & 0.39 \\
& 8 & 9 & 9 & 9 & $\mathrm{~b}-\mathrm{e}$ & $\mathrm{a}$ \\
& $\mathrm{def}$ & $\mathrm{g}$ & $\mathrm{g}$ & $\mathrm{c}-\mathrm{f}$ & & \\
Asam & 0.2 & 0.2 & 0.3 & 0.3 & 0.31 & 0.38 \\
askorbat & 6 & 2 & 6 & 5 & $\mathrm{~b}-\mathrm{e}$ & $\mathrm{ab}$ \\
& $\mathrm{ef}$ & $\mathrm{fg}$ & $\mathrm{ab}$ & $\mathrm{a}-\mathrm{d}$ & & \\
Tanpa & 0.3 & 0.2 & 0.3 & 0.3 & 0.34 & 0.39 \\
coating & 1 & 8 & 4 & 2 & $\mathrm{a}-\mathrm{e}$ & $\mathrm{a}$ \\
\hline
\end{tabular}

Pengaruh Coating terhadap Daya Simpan Benih Padi Hibrida Intani-2

Faktor tunggal perlakuan coating, periode simpan, maupun interaksi kedua faktor tunggal tidak berpengaruh nyata terhadap semua tolok ukur viabilitas dan vigor benih serta kadar air (Tabel 6.) 
Tabel 6. Rekapitulasi Sidik Ragam Pengaruh Perlakuan Coating dan Periode Simpan pada Benih Padi Hibrida Intani-2

\begin{tabular}{lcccc}
\hline \multicolumn{1}{c}{ Tolok } & \multicolumn{4}{c}{ Perlakuan } \\
\cline { 2 - 5 } \multicolumn{1}{c}{ Ukur } & PS & P & PSXP & KK $(\%)$ \\
KB & tn & tn & tn & 7.64 \\
KCT & tn & tn & tn & 7.39 \\
IV & tn & tn & tn & 16.84 \\
PTM & tn & tn & tn & 5.88 \\
BKKN & tn & tn & tn & 3.82 \\
KA & tn & tn & tn & 11.13 \\
\hline
\end{tabular}

Pada periode simpan 15 minggu benih masih memiliki viabilitas dan vigor yang tinggi terlihat dari daya berkecambah benih masih diatas $80 \%$. Kadar air benih selama penyimpanan juga masih dapat dipertahankan dibawah $11 \%$ terutama pada perlakuan coating menggunakan asam askorbat walaupun tidak menunjukkan nilai yang nyata berbeda (Tabel 7.)

Tabel 7. Pengaruh Perlakuan Coating terhadap Enam Tolok Ukur Viabilitas dan Vigor Benih pada Periode Simpan 15 Minggu

\begin{tabular}{lcccccc}
\hline \multirow{2}{*}{$\begin{array}{l}\text { Perlakuan } \\
\text { coating }\end{array}$} & DB & $\begin{array}{c}\text { KCT } \\
(\% / \mathrm{etm}\end{array}$ & $\begin{array}{c}\text { IV } \\
(\%)\end{array}$ & $\begin{array}{c}\text { PT } \\
\text { M }\end{array}$ & $\begin{array}{c}\text { BKK } \\
\text { N } \\
(\%)\end{array}$ & $\begin{array}{c}\text { KA } \\
(\%)\end{array}$ \\
\hline Bakteri & 84. & 21.52 & 75. & 94. & 0.30 & 10. \\
& 00 & & 33 & 67 & & 33 \\
Asam & 89. & 21.60 & 82. & 91. & 0.30 & 9.6 \\
askorbat & 33 & & 67 & 33 & & 7 \\
Tanpa & 87. & 21.38 & 81. & 95. & 0.33 & 10. \\
coating & 33 & & 33 & 33 & & 67 \\
\hline
\end{tabular}

Pengaruh Coating terhadap Daya Simpan Benih Padi Hibrida SL-8

Faktor tunggal perlakuan, periode simpan dan interaksinya berpengaruh sangat nyata terhadap tolok ukur daya berkecambah, kecepatan tumbuh dan indeks vigor namun tidak berpengaruh nyata terhadap tolok ukur potensi tumbuh maksimun dan kadar air. Faktor tunggal periode simpan berpengaruh sangat nyata terhadap tolok ukur bobot kering kecambah normal (Tabel 8.). Pada akhir periode simpan (15 minggu), perlakuan coating dan tanpa coating masih tetap dapat mempertahankan viabilitas benih terlihat dari nilai potensi tumbuh maksimum yang berkisar antara 96-96.67\%, serta kadar air yang berkisar antara 9.00-9.33\%.
Tabel 8. Rekapitulasi Sidik Ragam Pengaruh Perlakuan Coating dan Periode Simpan pada Benih Padi Hibrida SL-8

\begin{tabular}{lcccc}
\hline \multirow{2}{*}{ Tolok ukur } & \multicolumn{4}{c}{ Perlakuan } \\
\cline { 2 - 5 } & PS & P & PSXP & KK $(\%)$ \\
\hline DB & $* *$ & $* *$ & $* *$ & 3.98 \\
KCT & $* *$ & $* *$ & $* *$ & 4.08 \\
IV & $* *$ & $* *$ & $* *$ & 11.74 \\
PTM & tn & tn & tn & 3.18 \\
BKKN & $* *$ & tn & tn & 12.9 \\
KA & tn & tn & tn & 15.65 \\
\hline
\end{tabular}

Tabel 9. menunjukkan pengaruh yang nyata terhadap peningkatan daya berkecambah, kecepatan tumbuh, indeks vigor dan berat kering kecambah normal terutama pada periode simpan 15 minggu.

Tabel 9. Pengaruh Periode Simpan pada Benih Padi Hibrida SL-8

\begin{tabular}{ccccccc}
\hline Tolok & \multicolumn{6}{c}{ Periode simpan (minggu) } \\
\cline { 2 - 7 } ukur & 0 & 3 & 6 & 9 & 12 & 15 \\
\hline DB & 89.33 & 86.22 & 92.44 & 84.67 & 93.11 & 94.89 \\
$(\%)$ & $\mathrm{bc}$ & $\mathrm{cd}$ & $\mathrm{ab}$ & $\mathrm{d}$ & $\mathrm{a}$ & $\mathrm{a}$ \\
KCT & 18.96 & 17.91 & 19.72 & 18.88 & 18.56 & 21.31 \\
$(\%$ per & $\mathrm{c}$ & $\mathrm{d}$ & $\mathrm{b}$ & $\mathrm{c}$ & $\mathrm{cd}$ & $\mathrm{a}$ \\
etmal) & & & & & & \\
IV & 74.22 & 62.22 & 73.11 & 61.56 & 73.11 & 89.11 \\
$(\%)$ & $\mathrm{b}$ & $\mathrm{c}$ & $\mathrm{b}$ & $\mathrm{c}$ & $\mathrm{b}$ & $\mathrm{a}$ \\
BKKN & 0.29 & 0.19 & 0.30 & 0.34 & 0.33 & 0.39 \\
$(\mathrm{~g})$ & $\mathrm{d}$ & $\mathrm{e}$ & $\mathrm{cd}$ & $\mathrm{b}$ & $\mathrm{bc}$ & $\mathrm{a}$ \\
\hline
\end{tabular}

Perlakuan coating menggunakan asam askorbat memberikan hasil yang nyata lebih tinggi dibandingkan perlakuan lainnya terhadap tolok ukur kecepatan tumbuh dan indeks vigor (Tabel 10.).

Tabel 10. Pengaruh Perlakuan Coating pada Benih Padi Hibrida SL-8

\begin{tabular}{cccc}
\hline \multirow{2}{*}{ Tolok ukur } & \multicolumn{3}{c}{ Perlakuan } \\
\cline { 2 - 4 } & Bakteri & $\begin{array}{c}\text { Asam } \\
\text { askorbat }\end{array}$ & $\begin{array}{c}\text { Tanpa } \\
\text { coating }\end{array}$ \\
\hline DB & $86.22 \mathrm{~b}$ & $93.22 \mathrm{a}$ & $90.89 \mathrm{a}$ \\
KCT & $19.19 \mathrm{~b}$ & $19.83 \mathrm{a}$ & $18.66 \mathrm{c}$ \\
IV & $69.56 \mathrm{~b}$ & $77.56 \mathrm{a}$ & $69.56 \mathrm{~b}$ \\
\hline
\end{tabular}

Perlakuan coating menggunakan bakteri menghasilkan daya berkecambah tertinggi pada akhir penyimpanan, sedangkan perlakuan coating dengan asam askorbat menghasilkan daya berkecambah tertinggi pada periode simpan 3 minggu walaupun tidak berbeda nyata dibanding kotntrol. Pada periode simpan 9 minggu perlakuan coating menggunakan asam askorbat mampu sangat nyata meningkatkan tolok ukur daya berkecambah (Tabel 11.). 
Tabel 11. Interaksi Perlakuan dengan Periode Simpan terhadap Tolok Ukur Daya Berkecambah pada Benih Padi Hibrida SL-8

\begin{tabular}{lcccccc}
\hline \multirow{2}{*}{$\begin{array}{l}\text { Perlakuan } \\
\text { coating }\end{array}$} & \multicolumn{7}{c}{ Periode simpan (minggu) } \\
\cline { 2 - 7 } & 0 & 3 & 6 & 9 & 12 & 15 \\
\cline { 2 - 7 } Bakteri & 86.0 & 72.0 & 94.6 & 79.3 & 88.6 & 96.6 \\
& 0 & 0 & 7 & 3 & 7 & 7 \\
Asam & $\mathrm{de}$ & $\mathrm{g}$ & $\mathrm{abc}$ & $\mathrm{f}$ & $\mathrm{cd}$ & $\mathrm{a}$ \\
askorbat & 93.3 & 94.0 & 93.3 & 92.6 & 94.0 & 92.0 \\
& 3 & 0 & 3 & 7 & 0 & 0 \\
Tanpa & $\mathrm{Abc}$ & $\mathrm{abc}$ & $\mathrm{abc}$ & $\mathrm{a}-\mathrm{d}$ & $\mathrm{abc}$ & $\mathrm{a}-\mathrm{d}$ \\
coating & 88.6 & 92.6 & 89.3 & 82.0 & 96.6 & 96.0 \\
& 7 & 7 & 3 & 0 & 7 & 0 \\
& $\mathrm{~cd}$ & $\mathrm{a}-\mathrm{d}$ & $\mathrm{bcd}$ & $\mathrm{ef}$ & $\mathrm{a}$ & $\mathrm{ab}$ \\
\hline
\end{tabular}

Tolok ukur kecepatan tumbuh menunjukkan peningkatan di akhir penyimpanan baik pada perlakuan coating maupun tanpa coating. Perlakuan coating menggunakan bakteri berpengaruh sangat nyata pada kecepatan tumbuh benih terutama pada periode simpan 6 minggu dibandingkan perlakuan coating dengan asam askorbat maupun tanpa coating. Perlakuan coating menggunakan asam askorbat nyata lebih tinggi dibandingkan perlakuan lainnya pada periode simpan 9 minggu (Tabel 12.)

Tabel 12. Interaksi Perlakuan terhadap Tolok Ukur Kecepatan Tumbuh pada Benih Padi Hibrida SL-8

\begin{tabular}{lcccccc}
\hline Perlakuan & \multicolumn{7}{c}{ Periode simpan (minggu) } \\
\cline { 2 - 7 } coating & 0 & \multicolumn{7}{c}{6} & 9 & 12 & 15 \\
\cline { 2 - 7 } & \multicolumn{7}{c}{$\%$ per etmal } \\
Bakteri & 19.0 & 16.5 & 22.4 & 17.1 & 18.0 & 21.8 \\
& 3 & 2 & 8 & 7 & 8 & 6 \\
& $\mathrm{c}$ & $\mathrm{e}$ & $\mathrm{a}$ & $\mathrm{de}$ & $\mathrm{cd}$ & $\mathrm{ab}$ \\
Asam & 19.4 & 19.1 & 19.3 & 21.3 & 18.8 & 20.9 \\
askorbat & 0 & 4 & 6 & 3 & 2 & 2 \\
& $\mathrm{c}$ & $\mathrm{c}$ & $\mathrm{c}$ & $\mathrm{ab}$ & $\mathrm{c}$ & $\mathrm{b}$ \\
Tanpa & 18.4 & 18.0 & 17.3 & 18.1 & 18.7 & 21.1 \\
coating & 3 & 7 & 3 & 5 & 8 & 6 \\
& $\mathrm{~cd}$ & $\mathrm{~cd}$ & $\mathrm{de}$ & $\mathrm{cd}$ & $\mathrm{c}$ & $\mathrm{ab}$ \\
\hline
\end{tabular}

Tabel 13. perlakuan coating menggunakan bakteri nyata lebih tinggi pada periode simpan 6 minggu dibanding kontrol. Sementara pada periode simpan 9 minggu perlakuan coating menggunakan asam askorbat terbukti nyata lebih tinggi dibandingkan kontrol.
Tabel 13. Interaksi Perlakuan dan Periode Simpan terhadap tolok ukur Indeks Vigor pada Benih Padi Hibrida SL-8

\begin{tabular}{|c|c|c|c|c|c|c|}
\hline \multirow{3}{*}{$\begin{array}{l}\text { Perla } \\
\text { kuan } \\
\text { coati } \\
n g\end{array}$} & \multicolumn{6}{|c|}{ Periode simpan (minggu) } \\
\hline & 0 & 3 & 6 & 9 & 12 & 15 \\
\hline & \multicolumn{6}{|c|}{$\%$} \\
\hline $\begin{array}{l}\text { Bakte } \\
\text { ri }\end{array}$ & $\begin{array}{c}68.00 \\
\text { def }\end{array}$ & $\begin{array}{c}40.67 \\
\mathrm{~h}\end{array}$ & $\begin{array}{c}89.33 \\
a b\end{array}$ & $\begin{array}{c}60.67 \\
\text { efg }\end{array}$ & $\begin{array}{c}65.33 \\
\mathrm{~d}-\mathrm{g}\end{array}$ & $\begin{array}{c}93.33 \\
\mathrm{a}\end{array}$ \\
\hline $\begin{array}{l}\text { Asam } \\
\text { askor } \\
\text { bat } \\
\text { Tanp }\end{array}$ & $\begin{array}{c}78.00 \\
\text { bcd }\end{array}$ & $\begin{array}{c}77.33 \\
\text { bcd }\end{array}$ & $\begin{array}{c}76.00 \\
b-e\end{array}$ & $\begin{array}{c}73.33 \\
\text { cde }\end{array}$ & $\begin{array}{c}73.33 \\
\text { cde }\end{array}$ & $\begin{array}{c}87.33 \\
\text { abc }\end{array}$ \\
\hline $\begin{array}{l}\text { a } \\
\text { coati } \\
n g\end{array}$ & $\begin{array}{c}76.67 \\
\text { bcd }\end{array}$ & $\begin{array}{c}68.67 \\
\text { def }\end{array}$ & $\begin{array}{c}54.00 \\
\text { fgh }\end{array}$ & $\begin{array}{c}50.67 \\
\text { gh }\end{array}$ & $\begin{array}{c}80.67 \\
a-d\end{array}$ & $\begin{array}{c}86.67 \\
\text { abc }\end{array}$ \\
\hline
\end{tabular}

Viabilitas dan vigor benih padi hibrida yang diberi perlakuan coating maupun tanpa coating masih tinggi sampai akhir penyimpanan. Hal ini diduga karena kadar air benih yang masih terjaga selama periode simpan dan masih dalam batas aman penyimpanan sampai akhir periode simpan dengan rataan $9.70 \%$. Selama periode simpan kemasan penyimpanan yang digunakan adalah plastik poliethylen yang resisten terhadap uap air sehingga kadar air benih tetap terjaga dan viabilitas benih dapat dipertahankan. Giang dan Gowda (2007) menyatakan bahwa benih padi hibrida (KRH-2) yang dicoating menggunakan polimer (W Yellow) + kaptan + thiaram + gouch + super red $1 \mathrm{ml} / \mathrm{kg}$ pada 10 bulan penyimpanan, memiliki kadar air yang lebih aman $(<13 \%)$ dengan daya berkecambah $85.70 \%$ sementara benih yang disimpan dalam kain mengalami peningkatan kadar air yaitu sebesar $14.30 \%$ serta penurunan viabilitas yang ditunjukkan dengan rendahnya daya berkecambah yang dihasilkan yaitu $62.00 \%$.

Seed coating menggunakan polimer dan bakteri $P$. flourescens RH4003 serta polimer dan asam askorbat $350 \mathrm{ppm}$ pada tiga varietas padi hibrida selama penyimpanan memiliki respon yang berbeda terhadap masing-masing tolok ukur viabilitas dan vigor. Coating pada benih padi hibrida varietas Intani-2 tidak menunjukkan perbedaan yang nyata pada semua tolok ukur viabilitas dan vigor benih, sebaliknya benih padi hibrida varietas DG-1 dan SL-8 memberikan respon yang nyata baik terhadap perlakuan coating, periode simpan maupun interaksinya pada beberapa tolok ukur. SL-8 lebih responsif terhadap penyimpanan dan perlakuan yang diberikan dibandingkan DG-1 dan Intani-2. Pada SL-8 perlakuan asam askorbat menunjukkan pengaruh yang nyata terhadap peningkatan indeks vigor, kecepatan tumbuh serta daya berkecambah dibandingkan kontrol pada periode simpan 9 minggu. Perlakuan coating menggunakan bakteri juga menunjukkan pengaruh yang nyata lebih tinggi 
terhadap indeks vigor dan kecepatan tumbuh benih terutama pada periode simpan 6 minggu. Penelitian yang dilakukan oleh Mettananda et al. (2001) menunjukkan faktor genetik mempengaruhi perbedaan toleransi viabilitas 6 varietas padi terhadap kondisi lingkungan yang ditunjukkan dengan perbedaan daya berkecambah benih setelah mengalami penyimpanan. Benih padi varietas $\mathrm{Bg}$ 379-2, Bg 403 dan At 353 mampu mempertahankan viabilitas $(>85 \%)$ pada penyimpanan yang memiliki RH cukup tinggi (fluktuasi hingga 30\%) sampai delapan bulan penyimpanan sementara tiga varietas lainnya (Bg 300, 400 dan 352) hanya mampu mempertahankan viabilitas sampai 5 bulan penyimpanan (ketika 6 bulan penyimpanan daya berkecambah berada di kisaran 40-60\%).

Perlakuan coating menggunakan asam askorbat $350 \mathrm{ppm}$ dalam percobaan ini terbukti mampu meningkatkan viabilitas dan vigor benih padi hibrida di penyimpanan. Pada Intani-2 perlakuan asam askorbat mampu mempertahankan kadar air tetap rendah yaitu 9.67\%. Selain itu, perlakuan ini juga menghasilkan daya berkecambah, kecepatan tumbuh dan indeks vigor tertinggi walaupun tidak nyata berbeda dibandingkan perlakuan lainnya. Pada SL-8 perlakuan asam askorbat menghasilkan daya berkecambah (92.67\%) kecepatan tumbuh $(21.33 \%$ per etmal) dan indeks vigor $(73.33 \%)$ yang nyata lebih tinggi dibandingkan kontrol pada periode simpan 9 minggu. Pada DG-1 perlakuan ini mampu menghasilkan indeks vigor tertinggi secara nyata yaitu 90\% dibandingkan kontrol $61.33 \%$. Pemberian asam askorbat sebagai antioksidan pada benih diduga mampu memperlambat laju kemunduran benih di penyimpanan karena menangkal radikal bebas yang menjadi penyebab kemunduran benih. Hal ini sesuai dengan penelitian sebelumnya yang dilakukan oleh Lumbanraja dimana perlakuan perendaman benih pepaya sebelum peyimpanan dengan asam askorbat 350 ppm memiliki nilai potensi tumbuh maksimum nyata lebih tinggi dibandingkan kontrol selama periode simpan (12 minggu) yaitu $85.6 \%$ untuk perlakuan perendaman dengan asam askorbat dan $69.01 \%$ untuk kontrol. Dolatabadian dan Modarressanavy (2008) melaporkan pemberian asam askorbat 200 ppm pada benih Helianthus annus L. menghasilkan daya berkecambah sebesar $95.55 \%$ yang berbeda nyata dengan kontrol yaitu 86.67\%. Hamama (2008) menunjukkan perlakuan asam askorbat $55 \mathrm{mM}$ mampu secara nyata meningkatkan $\mathrm{K}_{\mathrm{CT}}$ benih jagung (Bisma) $16.38 \%$ per etmal dibanding kontrol $6.81 \%$ per etmal dan juga mampu meningkatkan indeks vigor secara nyata yaitu $42.67 \%$ dibanding kontrol 14\%.

Pada periode simpan 6 minggu perlakuan coating menggunakan bakteri pada benih padi hibrida SL-8 mampu secara nyata meningkatkan kecepatan tumbuh $22.48 \%$ per etmal dibandingkan kontrol $17.33 \%$ per etmal serta indeks vigor $89.33 \%$ dibandingkan kontrol $54.00 \%$. Peningkatan ini mungkin terkait dengan kemampuan bakteri $P$. flourescens dalam menghasilkan auksin yang berfungsi dalam perkembangan tunas, perpanjangan sel-sel batang serta akar. Kemampuan perlakuan coating menggunakan bakteri dalam mempengaruhi tolok ukur viabilitas yang berfluktuasi selama periode simpan mungkin disebabkan polimer yang digunakan tidak mengandung cukup nutrisi sehingga populasi bakteri tidak stabil. Kusumowardani (2008) menyatakan pertumbuhan populasi pada media LB sebagai kontrol lebih stabil dibandingkan dengan media alternatif lainnya, karena media ini mengandung banyak nutrisi yang dapat mendukung pertumbuhan $P$. flourescens. Kader et al. (2012) menambahkan coating benih menggunakan bakteri $P$. flourescens $10^{5}-10^{6} \mathrm{cfu} / \mathrm{ml}$ dengan bahan pembawa serbuk gergaji+cmc mampu mempertahankan viabilitas bakteri hingga 10 bulan (34.4 cfu/gr-34.0 cfu/gr). Selain itu, efektivitas bakteri Pseudomonas diduga kurang terlihat pada kondisi lingkungan yang tidak tercekam. Penelitian yang dilakukan oleh Husen (2012) menunjukkan inokulasi Pseudomonas pada tanah non steril memiliki bobot tanaman yang nyata lebih tinggi dibandingkan inokulasi pada tanah steril di pertanaman kedelai.

\section{KESIMPULAN}

Coating menggunakan bakteri Pseuodomonas flourescens terbukti dapat mempertahankan vigor benih padi hibrida di penyimpanan dengan tolok ukur indeks vigor dan kecepatan tumbuh. Sementara, coating menggunakan asam askorbat dapat mempertahankan viabilitas dan vigor benih padi hibrida di penyimpanan dengan tolok ukur daya berkecambah dan indeks vigor benih. Penyimpanan selama 15 minggu belum menurunkan viabilitas dan vigor benih padi hibrida. Perlakuan coating maupun tanpa coating tidak menurunkan viabilitas benih padi hibrida selama 15 minggu penyimpanan.

\section{DAFTAR PUSTAKA}

Anita, B, R. Samiyappan. 2012. Induction of systemic resistance in rice by Pseudomonas flouresecns against rice root knot nematode Meloidogyne graminicola. JBiopest 5 (supplementary):53-59.

Dadang W. I., Peni S. P., T. Mardi, Yan S., Slamet R. 2009. Padi hibrida, potensi besar berselimut masalah [Internet] [diunduh 2011 Maret 16] [Internet] [diunduh 2011 Maret 16] [Internet] [diunduh $2011 \quad$ Mar 16$]$ http://www.agrinaonline.com/redesign2.php?rid $=7 \&$ aid $=1729$. 
Deptan. 2007. Sosialisasi padi hibrida mendukung peningkatan produksi padi nasional. [Internet] [diunduh $2011 \quad$ Maret 16 ] http://www.litbang.deptan.go.id/press/one/1/pdf/.

Dolatabadian, A., S.A.M. Modarressanavy. 2008. Effect of the ascorbic acid, ayridoxine and hydrogen peroxide treatments on germination, catalase activity, protein dan malondialdehyde content of three oil seed. Not. Bot. Hort. Agrobot. Cluj 36 (2):61-66.

Giang, L.P., R. Gowda. 2007. Influence of seed coating with synthetic polymers and chemicals on seed quality and storability of hybrid rice (Oryza sativa L.). Omonrice 15:68-74.

Hamama, H. 2008. Pengaruh Perlakuan Asam Askorbat terhadap Viabilitas dan Vigor Bibit Jagung (Zea mays L.). Skripsi. Program Studi Pemuliaan Tanaman dan Teknologi Benih, Institut Pertanian Bogor. Bogor. 78 hal.

Husen, E. 2012. Studi Pseudomonas Penghasil ACC Deaminase dalam Meningkatkan Pertumbuhan dan Ketahanan Tanaman Kedelai terhadap Penyakit. Thesis. Sekolah Pasca Sarjana, Institut Pertanian Bogor. Bogor. 50 Hal.

Ilyas, S. 2006. Seed treatments using matriconditioning to improve vegetable seed quality. Bul. Agron. 34(2):124 - 132.

Jeon, J. S., S. S. Lee, H. Y. Kim, T. S. Ahn, H. G. Song. 2003. Plant growth promotion in soil by some inoculated microorganisms. The Journal of Microbiology 41(4):271-276.

Kader, M. M. A., N. S. El-Mougy, M.D.E. Aly, S. M. Lashin. 2012. Long activity of stored formulated bio-agents against some soil-borne plant pathogenic fungi causing root rot of some vegetable. Journal of appied sciences research 8(4):1882-1892.

Kusumowardani, A. 2008. Kajian Jenis Limbah, Suhu dan Lama Penyimpanan terhadap Daya Tahan dan Potensi Antagonisme Pseudomonas fluorescens. Skripsi. Jurusan Hama dan Penyakit Tumbuhan, Fakultas Perrtanian, Institut Pertanian Bogor. Bogor. 36 hal.

Kunkur, V., R. Hunje, N. K. Biradarpatill, B. S. Vyakarnhal. 2007. Effect of seed coating with polymer, fungicide and insecticide on seed quality in cotton during storage. Karnataka J. Agric. Sci.,20(1): (137 - 139).
Kazempour, M. N. 2004. Biological control of Rhizoctonia solani, the causal agent of rice sheath blight by antagonistics bacteria in greenhouse and field conditions. Plant Pathology Journal 3(2):88-96.

Khakipour, N. K. Khavazi, H. Mojallali, E. Pazira, H. Asadirahmani. 2008. Production of auxin hormone by fluorescent Pseudomonads. American-Eurasian J. Agric. \& Environ. Sci 4 (6): 687-692.

Lumbanraja, S.S.O. 2006. Pengaruh Pemberian Antioksidan Sebelum Simpan terhadap Viabilitas dan Vigor Benih Pepaya (Carica papaya L.). Skripsi. Program Studi Pemuliaan Tanaman dan Teknologi Benih, Institut Pertanian Bogor. Bogor. 40 hal.

Mettananda, K.A. , S.L. Weerasena, Y. Liyanage. 2002. Storability of rice (Oryza sativa L.) seed in improved warehouse. [Internet] [diunduh 2012 Jul 01] tersedia pada http://www.goviya.lk /agrilearning/Paddy/Paddy_Research/Paddy_pdf/ PH1.pdf.

Nawangsih, A. A. 2006. Seleksi dan Karakterisasi Bakteri Biokontrol untuk Mengendalikan Penyakit Layu Bakteri (Ralstonia solanacearum) pada Tomat. [disertasi]. Program Studi Entomologi/Fitopatologi, Sekolah Pasca Sarjana, Institut Pertanian Bogor. Bogor. 118 hal.

Pablico, S. M. 2006. Kandang hermetik menambah viabilitas benih padi hibrida. [Internet] [2011 Sept 26] tersedia pada http://www.seedquest.com /News/releases/2006/september/16889.htm.

Paul, D., Y. R. Sarma. 2005. Pseudomonas fluorescens mediated systemic resistance in black pepper (Piper nigrum L.) is driven through an elevated synthesis of defense enzymes. [Internet] [diunduh 2011 Okt 14] tersedia pada http://openmed.nic.in/130/02/System ic.pdf.

Srivastava, J. P., R. D. S. Yadav, S. C. Vimal. 2008. Improving stress management through seed enhancement in hybrid rice. [Internet] [diunduh 2011 Sept 26] tersedia pada http://www.cropresearch.org/pages/crarchivevol 35_no_12.htm.

Thobunluepop, P., E. Pawelzik, S. Vearasilp. 2008. The Perspective of various seed coating substances on rice seed variety Khao Dawk Mali 105 storability I: The Case Study of Physiological Properties. Pakistan Journal of Biological Sciences 11(19):2291-2299 